\title{
RENATA BURA
}

Uniwersytet Jagielloński

\section{NIEMIECKIE OBJAŚNIENIA NAWIASOWE W PRASIE GÓRNOŁUŻYCKIEJ}

\section{Wprowadzenie}

Tradycja wprowadzania objaśnień nawiasowych w prasie górnołużyckiej jest dość długa, ponieważ sięga jej początków, czyli połowy XIX wieku. Wówczas to, w okresie kształtowania się literackiego języka górnołużyckiego, nastąpił znaczny wzrost nowej leksyki. Język miał zaspakajać wszystkie kulturowe potrzeby tworzącego się nowoczesnego narodu. Takie podejście prowadziło przede wszystkim do pokazania leksykalnego bogactwa współczesnego języka poprzez usunięcie germanizmów i wprowadzenie w ich miejsce wyrazów rodzimych bądź (częściej) zapożyczeń z innych języków słowiańskich. Wprowadzanie i popularyzowanie nowej leksyki miało miejsce na łamach ówczesnej prasy. Nowym wyrazom towarzyszyły niemieckie objaśnienia nawiasowe. Od tamtej pory jest to stała cecha piśmiennictwa górnołużyckiego.

Tadeusz Lewaszkiewicz (1994: 75) słusznie zauważa, że: „Częste posługiwanie się w tekstach wtrętami nawiasowymi o charakterze metajęzykowym wiąże się ze specyficzną sytuacją językową narodu nie posiadającego własnego państwa. W historii języków rozwijających się w korzystnej sytuacji społeczno-politycznej nawiasowe objaśnianie wyrazów spotyka się rzadko". Niewątpliwie w takiej sytuacji znajduje się język górnołużycki i języki łużyckie w ogóle. Charakter języków mniejszościowych wobec dominującej niemczyzny, ograniczenie ich używania do pewnych sytuacji komunikacyjnych (przede wszystkim w rodzinie, w edukacji szkolnej, w publikacjach drukowanych oraz wśród personelu instytucji łużyckich), a także różny stopień ich znajomości przez użytkowników powodują, że konieczne jest objaśnianie mniej znanej lub nowej leksyki. Zaznaczyć jednak należy, że choć objaśnienia nawiasowe są stałym elementem w górnołużyckiej prasie, to różny jest stopień ich nasilenia. Zwykle wiąże się to $\mathrm{z}$ nagłym przyrostem nowego słownictwa. Kolejny taki okres miał miejsce po drugiej wojnie światowej, kiedy nastąpił rozwój nauki i techniki, a ponadto wprowadzono w szkołach język łużycki również do nauki przedmiotów przyrodniczych. Trzecia fala przypada na czasy po przewrocie politycznym w roku 1989. Wówczas to objaśniane są przede wszystkim nowe terminy z dziedziny polityki i ekonomii. To nowe słownictwo w znacznym stopniu rejestrują dziś najnowsze słowniki gór- 
nołużyckie, przede wszystkim zaś Němsko-hornjoserbski słownik noweje leksiki (2006; dalej: Noleks).

Ekscerpcję i badanie słownictwa z objaśnieniami nawiasowymi postuluje Tadeusz Lewaszkiewicz (por. 1994: 74-75). Zaproponowana przez niego metoda jest niewątpliwie bardzo efektywna. Pozwala ona bowiem zebrać w bardzo krótkim czasie (umożliwia to stosunkowo dobra widoczność nawiasów w tekście) bogaty materiał leksykalny do analizy, a także przeprowadzić badania statystyczne, które w jakimś stopniu pomogłyby w ocenie roli prasy górnołużyckiej w rozwoju leksyki tego języka. Jest to z pewnością metoda, którą warto podjąć w badaniach nad słownictwem górnołużyckiej prasy i leksyką górnołużycką w ogóle. Dotychczas oprócz Tadeusza Lewaszkiewicza $(1980,1994,1995)$ metodę tę w swoich badaniach wykorzystały Jadwiga Markec (2000) oraz Renata Bura (2012).

\section{Zakres i sposób prezentacji materiału}

Zaprezentowany niżej materiał został zgromadzony z rocznika 2011 „Serbskich Nowin”, górnołużyckiej popołudniówki, której początki sięgają XIX wieku1. Ekscerpcją objęto wydanie główne gazety (dalej skrót: SN), a także weekendowe dodatki: Předźenak (dalej skrót: SN-P), Kultura a wumétstwo (dalej: SN-KW) oraz Młodźina (dalej: SN-M). Zebrany materiał został sklasyfikowany pod względem semantycznym. Przy każdej grupie tematycznej podaje się w nawiasie liczbę objaśnionych wyrazów. Materiał prezentowany jest w następujący sposób: kursywą nazwa lub nazwy górnołużyckie (niekiedy autor podaje dwie synonimiczne nazwy; tu połączone są znakiem /; wyrazy prezentowane są w mianowniku liczby pojedynczej lub mnogiej - w zależności od formy odpowiednika niemieckiego), niemieckie objaśnienie nawiasowe, lokalizacja w tekście (skrót gazety, numer i strona, np. SN-M 214/4), w nawiasie liczba poświadczeń (jeśli dany wyraz występuje więcej niż raz, podaje się jedynie pierwszą lokalizację), a także odpowiednik polski, pozwalający zorientować się polskiemu odbiorcy co do charakteru objaśnianych jednostek. Nie tłumaczy się nazw instytucji, urzędów i organizacji, które objaśnia najczęściej skrót nazwy niemieckiej. W tym wypadku przy użyciu znaku = podaje się pełną nazwę niemiecką. Za pomocą symbolu // łączy się różne nazwy łużyckie z tym samym objaśnieniem niemieckim lub te same nazwy łużyckie z różnymi objaśnieniami niemieckimi. Materiał w poszczególnych grupach tematycznych ułożony został alfabetycznie według alfabetu górnołużyckiego w najnowszym wydaniu słownika ortograficznego Völkela (2005; dalej: Völkel2005): a, b, c, č, ć, d, dź, e, ě, f, g, h, ch, i, j, k, l, l, m, n, (ń) $)^{2}, o,(o ́), p, q, r$, ř, s, š, t, u, v, w, x, y, z, ž.

Zaprezentowany niżej materiał stanowi niewielką część badań obejmujących analizę słownictwa prasy górnołużyckiej (przede wszystkim „Serbskich Nowin”) z lat 2005-2014. Projekt, realizowany we współpracy z prof. Tadeuszem Lewaszkiewiczem, ma na celu ekscerpcję górnołużyckiej leksyki opatrzonej niemieckimi objaśnieniami nawiasowymi

\footnotetext{
1 Poczatkowo ukazywały się jako tygodnik „Tydźenska Nowina” pod red. H. Zejlera (1842-1848), a następnie „Tydźenske Nowiny” (1849-1853) pod red. J. A. Smolera.

${ }^{2}$ Litery umieszczone $\mathrm{w}$ nawiasach są przypisane w porządku alfabetycznym do poprzedzającego je znaku.
} 
i jej ocenę pod względem semantycznym, a także wychwycenie nowych wyrazów górnołużyckich i analizę ich budowy słowotwórczej.

\section{Klasyfikacja semantyczna zebranego materiału}

\section{Terminologia naukowa (163)}

a) Botanika (76): babyduška (Thymian): SN 78/4 - 'macierzanka'; baćonki (Storchenschnabel): SN 169/4 - 'bodziszek' (por. Völkel2005: baćonica = niem. Storchschnabel) // por. žorawnica (Storchschnabel): SN 91/4 - 'pelargonia' (por. NHS: Storchschnabel = 1. Geranium - pyskawa, baćonki plt.; 2. Pelargonium - žorawnica, pelargonija); barbjerski serpik (Färberscharte): SN 96/4 - 'sierpnik barwierski'; běła bónčawa (Weiße Seerose): SN 129/4 - 'grzybień biały'; bimbawka (Kuhschelle): SN 138/4 - 'sasanka'; brěčica / brěčkowc (Elsbeere): SN 13/4 // atlasowa jahoda (Elsbeere): SN 85/4 - 'jarząb brekinia' (głuż. atlasowa jahoda jest kalką niem. Atlasbeere, będącego pospolitym synonimem Elsbeere); buksowc (Buchsbaum): SN 3/4 - 'bukszpan'; čerwjeny hłohonc (Rotdorn): SN 64/4 - 'głóg czerwony'; ćéłowe zelo (Rosmarin): SN 13/4 - 'rozmaryn'; ćerpjenka / martrownica (Passionsblume): SN 13/4 - 'męczennica'; dwěnka (Zweiblatt): SN 96/4 - 'listera'; dwułopjenata kokulinda (Zweiblättrige Waldhyazinthe): SN 13/4 - 'podkolan biały'; hatna syćizna (Teichsimse): SN 129/4 - 'sitowie'; hnězdowka (Nestwurz): SN 91/4 (2×) - 'gnieźnik'; hórska žerchwica (Bitteres Schaumkraut): SN 119/4 - 'rzeżucha gorzka' (hórska jest tu błędem, powinno być hórka, por. głuż. Wiki: hórka žerchwica); hórski paproć (Bergfarn): SN 119/4 - 'zaproć górska'; hrimanka (Natternkopf): SN 78/4 (2×) - 'żmijowiec'; chmjel (Hopfen): SN 80/2 - 'chmiel'; jadrownik (Samenkapsel): SN 96/4 - 'torebka nasienna'; kanadiska złotnička (Goldrute): SN 174/4 - 'nawłoć' (por. NHS: Goldrute = złotnička; powinno być: Kanadische Goldrute 'nawłoć kanadyjska'); kapralc (Pfefferhütchen): SN 169/4 - 'trzmielina pospolita'; koralička (Korallenwurz): SN 96/4 - 'żłobik koralowy'; kraska (Kresse): SN 85/4 - 'rzeżucha; nasturcja?' (błędne ekwiwalenty - por. Völkel2005: kraska = niem. Kapuzinerkresse 'nasturcja', niem. Kresse = žerchej 'rzeżucha'); krawnik (Schöllkraut): SN 174/4 - 'glistnik jaskółcze ziele'; křemjenjate algi (Kieselalgen): SN 136/4 - 'okrzemki' (por. NHS: niem. Kieselalge = křemjenjowa / křemikowa alga / mokrica); łyknowc (Seidelbast): SN 91/4 - 'wawrzynek'; tyšćina (Gipskraut): SN 138/4 - 'łyszczec'; lěska (Hasel): SN 169/4 - 'leszczyna'; lěsna dornica (Waldschwingel): SN 91/4 - 'kostrzewa leśna'; lěsna fijałka (Waldveilchen): SN 91/4 - 'fiołek leśny'; lěsna jahlica (Waldhirse): SN 91/4 - 'prosownica rozpierzchła' (por. głuż. Wiki: lěsna pjerchowanka); lěsny čist (Waldziest): SN 169/4 - 'czyściec leśny'; lipnica (Rispengras): SN 174/4 - 'wiechlina'; liščak (Fuchsschwanz): SN 78/4 - 'wyczyniec'; marušnja (Maulbeerbaum): SN 8/3 - pol. 'morwa'; mjedwjedźica (Bärentraube): SN 138/4 - 'mącznica lekarska'; mokrica (Algen): SN 136/4 - 'glony, algi'; murjank (Mauerpfeffer): SN 174/4 - 'rozchodnik'; murski šleznik (Mauerraute): SN 174/4 - 'zanokcica murowa'; mydleško (Fetthenne): SN 13/4 (2×) - 'rozchodnik' // por. mydleško (Mauerpfeffer): SN 78/4 (niem. Mauerpfeffer i Fetthenne są nazwami synonimicznymi); paćernik (Perlgras): SN 91/4 'perłówka'; pazorak (Bärlapp): SN 91/4 - 'widłak'; pihawka (Knabenkraut): SN 96/4 'storczyk' // por. pihawka (Geflecktes Knabenkraut): SN 149/4 - 'storczyk plamisty, kukuk- 
ka plamista'; poćel (Zaunrübe): SN 174/4 - 'przestęp'; počepina (Traubenkirsche): SN 149/4 - 'czeremcha'; połon (Wermut): SN 174/4 - 'piołun'; porč (Wassersüßgras): SN 129/4 - 'manna mielec / wodna'; potačnik (Rohrkolben): SN 129/4 - 'pałka'; wulki pryskawc (Großes Springkraut): SN 169/4 - 'niecierpek'; rězna (Segge): SN 138/4 - 'turzyca'; rosowka (Sonnentau): SN-M 214/4 - 'rosiczka'; rutej (Rainfarn): SN 78/4 - 'wrotycz' (por. NHS: konjaca rutwica); sćénowc (Glaskraut): SN 174/4 - 'pomurnik'; sćina (Schilf): SN 129/4 - 'trzcina'; smjerdnička (Ringelblume): SN 85/4 - 'nagietek'; stróźawka (Flockenblume): SN 119/4 - 'chaber' // por. stróžawka (Wiesen-Flockenblume): SN 78/4 - 'chaber łąkowy'; sukač (Knäuelgras): SN 96/4 - 'kupkówka'; swěčnikojte algi (Armleuchteralgen): SN 136/4 - 'ramienicowe'; syćel (Hainsimse): SN 217/4 - 'kosmatka'; sydrik (Labkraut): SN 217/4 - 'przytulia'; šćér (Bingelkraut): SN 174/4 - 'szczyr'; šlěz (Malve): SN 85/4 -'ślaz' // por. šlez (Rosenmalve): SN 169/4 - 'ślaz zygmarek' (reg. šlez = šlěz); trudownik (Braunwurz): SN 91/4 - 'trędownik'; wjerbojty staršik (Weidenkreuzkraut): SN 91/4 - 'gatunek starca'; woblěd (Bilsenkraut): SN 174/4 - 'lulek'; wódrak (Borretsch): SN 85/4 - 'ogórecznik lekarski'; wonjata serlica (Waldmeister): SN 91/4 - 'przytulia / marzanka wonna'; wowsnik (Glatthafer): SN 78/4 - 'rajgras'; wšědna kłósnička (Moorlilie): SN 13/4 - 'łomka zachodnia' (por. NHS: kłósknička oraz głuż. Wiki: wšědna kłósknička); wutlik (Weichwurz): SN 96/4 'wątlik'; wysoki kropačk (Hohe Schlüsselblume): SN 91/4 (3×) - 'pierwiosnek wyniosły'; zahrodna běłonka (Mutterkraut): SN 174/4 - 'wrotycz maruna'; zaječica (Hasenlattich): SN 91/4 - 'przenęt purpurowy'; zubica (Zahnwurz): SN 217/4 - 'żywiec'.

b) Zoologia (52): babjenska krokawa (Geburtshelferkröte): SN 63/4 - 'Alytes (płaz)'; buwot (Büffel): SN 236/4 - 'bawół'; cycadto (Saugrüssel): SN 101/4 - 'ssawka'; čerwjeń (Rotlauf): SN 170/4 - 'tu: różyca (choroba świń)'; čerwjena wopuška (Gartenschwanz): SN 18/4 - 'pleszka' (por. NHS: Rotschwänzchen); čěrka (Krickente): SN 129/4 - 'cyraneczka'; dańk (Damwild): SN-P 248/5 - 'daniel'; dudka (Puppe): SN 101/4 - 'poczwarka'; htuchar (Auerhahn): SN 107/2 - 'głuszec'; husańca (Raupe): SN 101/4 - 'gąsienica'; chójnowa pata (Kiefernspinner): SN 101/4 - 'barczatka sosnówka'; chójnowy frunčak (Kiefernschwärmer): SN 101/4 - 'zawisak borowiec'; Jakubowe wowcy (Jakobsschaf): SN 73/4 'owca Jacoba' // wowca z wjacorymi rohami (Mehrhornschaf): SN 73/4 - 'owca wieloroga' (nazwy Jakobschaf i Mehrhornschaf są synonimami); tastojča wopuš (Schwalbenschwanz): SN 101/4 - 'paź królowej'; tasyčka (Frettchen): SN 241/4 - 'fretka domowa'; łobjowski bobr (Elbebiber): SN 33/4 - 'bóbr europejski'; tós (Elch): SN-P 65/2 - 'łoś'; tysačk (Blessente): SN 129/4 - 'łyska'; lěsna wiwka (Waldkauz): SN 226/4 - 'puszczyk'; lipon (Äsche): SN 18/4 - 'lipień (ryba)'; mała kanja (Rohrweihe): SN 129/4 (2×) - 'błotniak stawowy'; mały myšowušaty [njetopyr] (Kleines Mausohr): SN-P 210/3 - 'nocek wschodni'; maty nurjak (Zwergtaucher): SN 129/4 - 'perkozek' (por. Tbio: nurjacy bibibik); měchinošer (Sackträger): SN 101/4 - 'koszówka (motyl)'; mlóčeńcowy frunčak (Wolfsmilchschwärmer): SN 101/4 - 'zmrocznik wilczomleczek'; mólički škličkowc (Zierliche Tellerschnecke): SN 18/4 - 'zatoczek łamliwy (ślimak)'; muflon (Muffelwild): SN-P 248/5 - 'muflon'; murska ješćelca (Mauereidechse): SN 18/4 - 'jaszczurka murowa' (por. NHS: niem. Mauereidechse = ćmowa ješćelca); niša dźiwina (Niederwild): SN-P 248/5 - 'zwierzyna drobna' (por. NHS: niska dźiwina); pasowc (Gürteltier): SN 178/2 - 'pancernik'; płóšak (Rochen): SN 58/4 - 'płaszczka'; pozemski lehnjak (Bodenbrüter): SN 43/4 - 'ptaki zakładające gniazda na ziemi'; prózdnjeńcowy mjedwjedź (Höhlenbär): SN-P 65/2 - 'niedźwiedź jaski- 
niowy'; ramuška (Beutelmeise): SN 129/4 - 'remiz zwyczajny'; rjehork (Schwarzhalstaucher): SN 129/4 - 'perkoz zausznik'; rubježne bruki (Raubfliegen): SN 38/4 - 'łowikowate' (por. Kral: rubježne muchi); rys (Luchs): SN 18/4 (3×) - 'ryś'; skórnik (Borkenkäfer): SN 72/1 - 'kornik'; sob (Rentier): SN-P 65/2 - 'renifer'; šmrěkowy křižik (Fichtenkreuzschnabel): SN 91/4 - 'krzyżodziób świerkowy'; šup (Waschbär): SN 22/4 - 'szop pracz'; tchór (Iltis): SN 241/4 - 'tchórz'; tupifila (Gimpel): SN 208/4 - 'gil'; wjerjabka (Haselhuhn): SN 91/4 - 'jarząbek'; wotmaty nosorohač (Wollnashorn): SN-P 65/2 - 'nosorożec włochaty'; wućahowaty sokoł (Wanderfalke): SN 107/2 - 'sokół wędrowny'; wudra (Fischotter): SN 107/2 - 'wydra'; wulki myšowušaty njetopyr (Großes Mausohr): SN 18/4 'nocek duży'; wulki prebłyšćowak (Großer Schillerfalter): SN 18/4 (2×) - 'mieniak tęczowiec (motyl)'; zymska lačawka (Wintergoldhähnchen): SN 91/4 - 'mysikrólik zwyczajny (ptak)'; zubr (Wisent): SN-P 65/2 (2×) - 'żubr'.

c) Anatomia i medycyna (13): brjušne slinicy (Bauchspeicheldrüsen): SN 44/4 - 'trzustki'; kompjuterowa tomografija (CT): SN 170/2 - 'tomografia komputerowa' (por. niem. Computertomographie / Computertomografie; stąd skrót CT); kosćica (Knochenhaut): SN 213/5 - 'okostna'; magnetowa rezonancna tomografija (MRT): SN 170/2 - 'tomografia rezonansu magnetycznego, rezonans magnetyczny' (por. niem. Magnetresonanztomographie) // por. magnetorezonancny tomograf (MRT): SN 223/4 - 'tomograf magnetyczno -rezonansowy' (por. niem. Magnetresonanztomograph); pospěšenje impulsa (Impulsbeschleunigung): SN 213/5 - 'przyspieszenie przewodzenia bodźców'; preimplataciska diagnostika (PID): SN 130/2 (2×) - 'diagnostyka preimplantacyjna' (skrót PID pochodzi od niem. Präimplantationsdiagnostik); słabina (Leiste): SN 236/1 - 'pachwina'; šére mjadro (grauer Star): SN 144/3 - 'zaćma'; wobwutrobno (Herzbeutel): SN 144/2 'osierdzie'; zahorjenje brónicy (Netzhautentzündung): SN 144/3 - 'zapalenie siatkówki'; zelene mjadro (grüner Star): SN 144/3 - 'jaskra'; zhibadłowe tobołki (Gelenkkapseln): SN 213/5 - 'torebki stawowe'.

d) Technika (5): błótnik (Kotflügel): SN 70/4 - 'błotnik'; drjewowe třěski (Holzpellets): SN 40/1 - 'pellety (materiał opałowy)'; spała (Klöppel): SN 5/2 - 'tu: serce dzwonu'; sykane třěski (Hackschnitzel): SN 40/1 - 'zrębki (opałowe)'; zakładny wukon (Grundlast): SN 104/2 - 'obciążenie podstawowe'.

e) Geologia (4): bryła (Raseneisenstein): SN 102/5 - 'ruda darniowa'; dwubłyšćinkowy zornowc (Zweiglimmergranit): SN 91/4 - 'granit dwułyszczykowy'; šćépjelowy płun (Schiefergas): SN 107/2 - 'gaz łupkowy'; šěrawc (Grauwacke): SN-P 25/2 (2×) - 'szarogłaz (odmiana pisakowca)'.

f) Architektura (4): chłódnica (Lusthaus): SN 130/2 - 'altana, pawilon'; knježi domom (Herrenhaus): SN-P 5/2 - 'dworek, rezydencja'; wětrnik na kózłach (Bockwindmühle): SN-P 228/3 - 'koźlak, wiatrak kozłowy'; wódny hród (Wasserburg): SN-P 146/3 - 'zamek wodny'.

g) Geografia (3): niske bahno (Niedermoor): SN 189/4 - 'torfowisko niskie'; skalny wustupk (Felsvorsprung): SN-M 195/3 - 'klif' (por. Tsta: skalny wuběžk); wysoke bahno (Hochmoor): SN 189/4 - 'torfowisko wysokie'. 
h) Chemia (3): škleńčowina (Flüssigglas): SN 68/2 - 'szkło wodne'; tetrahydrocannabinolowa kisalina (THC): SN 209/4 - 'tetrahydrokannabinol' (skrót THC pochodzi od niem. Tetrahydrocannabinol); woniki (Duftstoffe): SN 208/1 - 'substancje zapachowe'.

i) Prawo (3): prawniski hladar (Rechtspfleger): SN 122/4 - 'referendarz sądowy' (por. Noleks: prawnik); rukowanska winowatosć (Haftpflicht): SN 6/2 - 'odpowiedzialność cywilna'; zjednoćenstwo regionow (Gebietskörperschaft): SN 245/2 - 'państwowa jednostka organizacyjna' (por. Noleks: teritorialna korporacija; Tgeo: wobwodne zjednoćenstwo).

\section{2. Życie społeczne (18)}

a) Gospodarka, finanse, handel (9): akcijna towaršnosć (AG = Aktiengesellschaft): SN 150/2 - 'spółka akcyjna' (por. Noleks: akcijowe / akcijne towarstwo); dawk na hłowu (Kopfsteuer): SN 29/4 - 'podatek pogłówny'; etatowe zawěsćenje (Haushaltssicherung): SN 168/1 - 'zabezpieczenie budżetu'; integrowane wjesne wuwiće (ILE = Integriert Ländliche Entwicklung): SN 24/4 // Integrowane wuwiće na wsach (ILE): SN 101/4 (2×) // Integrowane wuwiće wsow (ILE): SN 100/4 // integrowane wuwiće na wsy (ILE): SN 94/4 // integrowane wuwiće na kraju (ILE): SN 88/2 - 'zintegrowany rozwój obszarów wiejskich'; nutřkokrajny bruttoprodukt (BIP = Bruttoinlandsprodukt): SN 80/1 (3×)// tukrajny bruttoprodukt (BIP): SN 100/2 'produkt krajowy brutto'; powšitkowne wobchodne wuměnjenja (AGB = Allgemeine Geschäftsbedingungen): SN 49/4 'ogólne warunki handlowe'; tuchwilna hódnota (Verkehrswert): SN 122/4 - 'wartość rynkowa'; wuchowanski fonds eura $($ EFSF $=$ Europäische Finanzstabilisierungsfazilität; por. ang. European Financial Stability Facility): SN 169/2 // wuchowanske krywo za euro (EFSF): SN 191/2 (4×) - 'Europejski Fundusz / Instrument Stabilizacji Finansowej'; wulkopřetrjebar (Großverbraucher): SN-P $83 / 4$ - 'odbiorca hurtowy'.

b) Edukacja, praca (7): centrum za horni schodźenk (OSZ = Oberstufenzentrum): SN 5/1 - 'typ szkoły zawodowej oferującej kształcenie po ukończeniu szkoły podstawowej'; dobrowólne socialne lěto (FSJ = freiwilliges soziales Jahr): SN 23/1 (4×) - 'dobrowolny rok socjalny (forma wolontariatu)'; nadzawodowy wukubłanski centrum (ÜAZ = überbetriebliches Ausbildungszentrum): SN 15/2 - 'międzyzakładowe centrum kształcenia'; powołanskokubłanski centrum (BBZ = Berufsbildungszentrum): SN 15/2 - 'ośrodek kształcenia zawodowego'; spočatne kwalifikaciske lěto (Einstiegsqualifizierungsjahr): SN 28/1 - 'rodzaj praktyki dla młodych ludzi'; Wysoka šula Łužica (FH = Fachhochschule): SN 83/2 (2×) (por. Noleks: Fachhochschule - fachowa wysoka šula); zwjazkowa dobrowólna stužba $(\mathrm{BFD}=$ Bundesfreiwilligendienst): SN 98/4 (4×) - 'federalna dobrowolna służba (rodzaj wolontariatu)'.

c) Relacje międzyludzkie (2): patchworkowe swójby (Patchworkfamilien): SN 146/3 'rodziny patchworkowe'; tučelowe swójby (Regenbogenfamilien): SN 146/3 - 'tęczowe rodziny'. 
3. Nazwy instytucji, urzędów, organizacji, związków itp. ${ }^{3}$ (106): Alternatiwny kulturny a kubłanski centrum [w Pirnje] (AkuBiZ = Alternatives Kultur- und Bildungszentrum): SN 23/3; Budyska bydlenjotwarska towaršnosć (BWB = Bautzener Wohnungsbaugesellschaft): SN 125/1 (3×); Budyske energijowe a wodowe zawody (EWB = Energie- und Wasserwerke Bautzen): SN 105/1 (2×); Budyski regionalny zarjad Sakskeje kubłanskeje agentury (SBAB = Sächsische Bildungsagentur, Regionalstelle Bautzen): SN 106/1 (6×); Dobroćelski dźéłaćerski skutk (AWO = Arbeiterwohlfahrt): SN-M 30/3 // Dźéłaćerske dobroćelstwo (AWO): SN-M 107/4 (2×) // Dźéłaćerski dobroćelstwowy skutk (AWO): SN 164/4; Centralny komitej němskich katolikow (ZdK = Zentralkomitee der deutschen Katholiken): SN 81/3; Centrum za mjezydisciplinarne pólske studije ( $\mathrm{ZiP}=$ poprawnie ZIP: Zentrum für Interdisziplinäre Polenstudien): SN 119/3; Dźéłarnistwo némskich lokomotiwnikow (GdL = Gewerkschaft Deutscher Lokomotivführer): SN 40/2 (6×) // Dźéłarnistwo lokomotiwnikow (GdL): SN 45/2 (7×); dźéłarnistwo policije (GdP = Gewerkschaft der Polizei): SN 98/2; dźéłarnistwo wučerjow (GEW = Gewerkschaft Erziehung und Wissenschaft): SN 44/2 // dźéłarnistwo za kubłanje a wědomosć (GEW): SN 47/1 // Dźéłarnistwo kubłanje a wědomosć (GEW): SN 185/1; Dźéłarnistwo železnicy a wobchada (EVG = Eisenbahn- und Verkehrsgewerkschaft): SN 7/2; Ekumeniska rada cyrkwjow (ÖRK = Ökumenischer Rat der Kirchen): SN 62/3 (4×); Europska centralna banka (EZB = Europäische Zentralbank): SN 95/2 (8×); Europski fonds za regionalne wuwiće (EFRE = Europäischer Fonds für regionale Entwicklung): SN 47/2 (2×); Ewangelska cyrkej srjedźneje Němskeje (EKM = Evangelische Kirche in Mitteldeutschland): SN 156/2; Ewangelska cyrkej w Němskej (EKD = Evangelische Kirche in Deutschland): SN 32/3 (13×) // Ewangelska cyrkej Němskeje (EKD): SN 186/1; Federalistiska unija europskich narodnych mjeńšin (FUEN = Föderalistische Union Europäischer Volksgruppen): SN 49/2 (11×)// Federalistiska unija europskich narodnych skupin (FUEN): SN 188/1; industrijne dźéłarnistwo hórnistwo, chemija, energija (IGBCE = Industriegewerkschaft Bergbau, Chemie, Energie): SN 120/7; Industrijowa a wikowanska komora (IHK = Industrie- und Handelskammer): SN 16/4 (2×) // Industrijna a wikowanska komora (IHK): SN 38/2 (8×); Institut za makroekonomiju a přeslédźenje konjunktury (IMK = Institut für Makroökonomie und Konjunkturforschung): SN 87/2; Kamjenska wobchadna towaršnosć zwr (KMVG = Kamenzer Verkehrsgesellschaft mbH): SN 83/3; Katolske zjednoćenstwo kubłarjow (KEG = Katholische Erziehergemeinschaft): SN 112/4; Komunalny socialny zwjazk (KSV = Kommunaler Sozialverband): SN 159/4; Konferenca cyrkwjow Europy (KEK = Konferenz Europäischer Kirchen): SN 62/3 // Konferenca europskich cyrkwjow (KEK): SN 207/3; koordinaciski běrow fanowych projektow (KOS = Koordinationsstelle Fanprojekte): SN 211/2; Krajna agentura za strukturu a dźéło (LASA = Landesagentur für Struktur und Arbeit): SN 220/1; Krajna banka Sakskeje (Sachsen LB $=$ Landesbank Sachsen): SN 175/2; Krajny kriminalny zarjad (LKA = Landeskriminalamt): SN 163/2 (2×); Křesćansko-socialny kubłanski skutk (CSB = Christlich-Soziales Bildungswerk): SN 3/4 (17×) (również konkretnie jako: Křesćansko-socialny kubłanski skutk Sakskeje / Sakska lub Miłočanski Křesćansko-socialny kubłanski skutk);

\footnotetext{
3 Wykaz nie obejmuje górnołużyckich nazw niemieckich partii politycznych opatrzonych skrótem nazwy niemieckiej. Podobnie bowiem objaśnia się czy konkretyzuje nazwy partii z innych krajów, por. strona Prawo a sprawnosć (PiS), Wobydlerska strona (ODS) [czes. ODS = Občanská demokratická strana]. Ponadto zachowana zostaje oryginalna pisownia wielką i małą literą.
} 
Křesćanski zwjazk młodych ludźi (CVJM = Christlicher Verein Junger Menschen): SN 110/4 (por. Noleks: (wcześniej) Christlicher Verein junger Männer - Křesćanski zwjazk młodych mužow); Łužiska a srjedźoněmska towaršnosć hórnistwoweho zarjadnistwa (LMBV = Lausitzer und Mitteldeutsche Bergbau-Verwaltungsgesellschaft): SN 5/1 (8×); Łužiska hospodarska iniciatiwa (WiL = Wirtschaftsinitiative Lausitz): SN 69/1 (5×); Łužiskie wubédźowanje załožerjow firmow (LEX = Lausitzer Existenzgründer Wettbewerb): SN 74/4 (3×) // por. Łužiske myto załožerjow firmy 2011 (LEX): SN 208/1; Łužiski koporowy šćěpjel tzwr (KSL = Kupferschiefer Lausitz GmbH): SN 29/3 // // Łužiski koporowy šćépjel (KSL): SN 70/1 // Towaršnosć koporowy šćěpjel Łužica (KSL): SN 75/1 // Koporowy šćěpjel Łužica tzwr (KSL): SN 178/7; Marketingowa towaršnosć Hornja Łužica-Delnja Šleska (MGO = Marketing-Gesellschaft Oberlausitz-Niederschlesien mbH): SN 168/1 (5×); medicinsko-zastaranski centrum [ užica] (MVZ = medizinisches Versorgungszentrum): SN 144/3; ministerstwo za statnu bjezstrašnosć (MfS = Ministerium für Staatssicherheit): SN 248/8; Mjezynarodna přirodna wustajeńca (INA = Internationale Naturausstellung): SN 3/2; Mjezynarodna turistiska bursa (ITB = Internationale Tourismus-Börse): SN 50/2 (2×); Mjezynarodna twarska wustajeńca (IBA = Internationale Bauausstellung): SN 93/2 (2×); Mjezynarodny komitej Čerwjeneho křiža (IKRK = Internationales Komitee vom Roten Kreuz): SN 193/3; Mjezynarodny měnowy fonds (IWF = Internationaler Währungsfonds): SN 86/1 (13×); Němska jednota towaršnosće za planowanje a twar dalnodróhow (DEGES = Deutsche Einheit Fernstraßenplanungs- und -bau): SN 4/6; Němska lodohokejowa liga (DEL = Deutsche Eishockey Liga): SN 32/3; Němska towaršnosć $k$ wuchowanju žiwjenja (DLRG = Deutsche Lebens-Rettungs-Gesellschaft): SN 168/4; Němska železnica (DB = Deutsche Bahn): SN 6/2 (4×); Němske dawkowe dźéłarnistwo (DSTG = Deutsche SteuerGewerkschaft): SN 124/2; Němske lětanske zawěsćenje (DFS = Deutsche Flugsicherung): SN 153/2; Němski čerwjeny křiž (DRK = Deutsches Rotes Kreuz): SN 103/2 (3×); Němski dźéłarniski zwjazk (DGB = Deutscher Gewerkschaftsbund): SN 7/1 (2×) (por. Noleks: Němski zwjazk dźéłarnistwow); Němski geoslédźenski centrum (GFZ = Deutsches GeoForschungsZentrum): SN 4/2; Němski koparski zwjazk (DFB = Deutscher Fußballbund): SN 149/1 (8×); Němski mjetarski zwjazk (DHB = Deutscher Handballbund): SN 243/1; Němski olympiski sportowy zwjazk (DOSB = Deutscher Olympischer Sportbund): SN 150/1; Němski zwjazk orchestrow (DOV = Deutsche Orchestervereinigung): SN 14/6 // Němske zjednoćenstwo orchestrow (DOV): SN 212/2; Němski wikowanski zwjazk (HDE = Handelsverband Deutschland): SN 117/2; Němski wysokošulski zwjazk (DHV = Deutscher Hochschulverband): SN 40/2; Němski zwjazk žurnalistow (DJV = Deutscher Journalistenverband): SN 26/2 // Němski žurnalistiski zwjazk (DJV): SN 216/2 (por. Noleks: Zwjazk žurnalistow Němskeje); Organizacija za wěstotu a zhromadne dźéło w Europje (OSZE = Organisation für Sicherheit und Zusammenarbeit in Europa): SN 1/2; Powšitkowny němski kolesowy klub (ADFC = Allgemeiner Deutscher Fahrrad-Club): SN 62/2; Přirodoškitny zwjazk Němska (NABU = Naturschutzbund): SN 238/2; Rada mjezsobneje hospodarskeje pomocy $(\mathrm{RGW}=$ Rat für gegenseitige Wirtschaftshilfe): SN-P 238/2 (por. Tsta: Rada wzajomneje hospodarskeje pomocy); ratarske prodrustwo (LPG = Produktionsgenossenschaft): SN 20/2; Regionalbus Hornja Łužica (RBO = Regionalbus Oberlausitz): SN 5/1 (2×); regionalna dźétarnička za kubłanje, demokratiju a žiwjenske perspektiwy (RAA = Regionale Arbeitsstelle für Bildung, Demokratie und Lebensperspektiven): SN 182/1; rjemjeslniska komora [Choćebuz] (HWK = Handwerkskammer): SN 145/2; Sakske ministerstwo za wob- 
swět a ratarstwo (SMUL $=$ Sächsisches Staatsministerium für Umwelt und Landwirtschaft): SN 46/1; Sakski krajny kuratorij wjesny rum (SLK = Sächsisches Landeskuratorium Ländlicher Raum): SN 6/4 (2×); Sakski krajny ratarski zwjazk (SLB = Sächsischer Landesbauernverband): SN 6/1 // Sakski krajny zwjazk ratarjow (SLB): SN 74/1 // Krajny zwjazk sakskich ratarjow (SLB): SN 123/1; Sakski kubłanski institut (SBI = Sächsisches Bildungsinstitut): SN 119/2; Sakski wikowanski zwjazk (HVS = Handelsverband Sachsen): SN 86/1; Sakski wukubłanski a wupruwowanski kanal (SAEK = Sächsische Ausbildungs- und Erprobungskanäle): SN 36/4 (7×); Sakski zwjazk wučerjow (SLV = Sächsischer Lehrerverband): SN 185/1; Samostatna ewangelsko-lutherska cyrkej (SELK = Selbständige Evangelisch-Lutherische Kirche): SN 187/1 (2×); Serbskopazličanske karnewalowe towarstwo (WCV = Wendischbaselitzer Carnevalsverein): SN 220/4; Srjedźoněmska regioželeznica (MRB = Mitteldeutsche Regiobahn): SN 61/2; Srjedźoněmski rozhłos (MDR = Mitteldeutscher Rundfunk): SN 151/1; Techniski pomocny skutk (THW = Technisches Hilfswerk): SN $52 / 2(3 \times)$; towaršnosć za měšćanske wuwiće ( $\mathrm{SEH}=$ Stadtentwicklungsgesellschaft): SN 8/1 (2×) // měšćanska wuwićowa towaršnosć (SEH): SN 93/4 (2×) (por. Noleks: Bundesministerium für Verkehr, Bau und Stadtentwicklung - Zwjazkowe ministerstwo za wobchad, twarstwo a wuwiće městow); Towaršnosć za wu-a dalekubłanje (GAF = Gesellschaft für Aus- und Fortbildung): SN 22/4 (6×); Towaršnosć za wuwiće struktury a dźéłowych wikow (DAS GmbH = [poprawnie DSA Dienstleistungen für Struktur- und Arbeitsmarktentwicklung $\mathrm{GmbH}]$ ): SN 15/1; turistiske zjednoćenstwo kónčiny Łužiska jězorina (TGG = Touristische Gebietsgemeinschaft „, Lausitzer Seenland”): SN 101/1 // Turistiske kónčinowe zjednoćenstwo tužiska jězorina (TGG): SN 236/3 // por. projektowy běrow koordinowanja Łužiskeje jězoriny, turistiske teritorialne zjednoćenstwo (TGG): SN 191/4; Turizmo-marketingowe towarstwo Sakskeje zwr (TMTS = Tourismus Marketing Gesellschaft Sachsen $\mathrm{mbH}$ ): SN 60/4; wobdźélenska a wobhospodarjenska towaršnosć (BBB = Beteiligungsund Betriebsgesellschaft Bautzen): SN 134/4 (2×) // Wobdźělenska a wobhospodarjenska towaršnosć Budyšin (BBB): SN 232/4; wobchadna towaršnosć Čorny Halštrow (VSE = Verkehrsgesellschaft Schwarze Elster): SN 148/4 (2×); Wobchadny zaměrowy zwjazk Hornje Łobjo (VVO = Verkehrsverbund Oberelbe): SN 3/1 (2×); Wojerowska energiju dobywaca towaršnosć (EEH = Energie Erzeugungsgesellschaft Hoyerswerda): SN 216/4; Wojerowski zastaranski zawod $(\mathrm{VBH}=$ Versorgungsbetriebe Hoyerswerda): SN 67/1; Wuchodoněmska železnica (ODEG = Ostdeutsche Eisenbahn): SN 5/1 (4×); wuchodosakska załožba lutowarnjow (OSS = Ostsächsische Sparkasse): SN 126/3; wukubłanski zwjazk Großröhrsdorf (AVG = Ausbildungsverbund Großröhrsdorf): SN 209/2; Zaměrowy zwjazk wobchadne zjednoćenstwo hornje Łobjo (ZVOE = Zweckverband Verkehrsverbund Oberelbe): SN 228/3; zaměrowy zwjazk wobchadniskeho zjednoćenstwa Hornja Łužica-Delnja Šleska (ZVON = Zweckverband Verkehrsverbund Oberlausitz-Niederschlesien): SN 150/2 // Zaměrowy wobchadny zwjazk Hornja Łužica-Delnja Šleska (ZVON): SN 207/1 (por. Noleks: Zweckverband - zaměrowy zwjazk, Verkehrsverbund - wobchadny zwjazk); zaměrowy zwjazk za woptóčki [Při Klóšterskej wodźe] (AZV = Abwasserzweckverband): SN 13/4 (7×) // Wopłóčkowy zaměrowy zwjazk [Při Klóšterskej wodźe] (AZV): SN 110/1; zarjady a organizacije $z$ wěstotnymi nadawkami (BOS = Behörden und Organisationen mit Sicherheitsaufgaben): SN 56/4; Zhromadny centrum wotwobaranja (GAR = Gemeinsames Abwehrzentrum gegen Rechtsextremismus) prawicarskeho ekstremizma: SN 243/2; Zwjazk němskich městow a gmejnow (DStGB = Deutscher Städte- und Gemeindebund): SN 78/2; 
Zwjazk němskich nowinskich nakładnikow (BDZV = Bundesverband Deutscher Zeitungsverleger): SN 160/2; Zwjazk za němske kulturne poćahi do wukraja (VDA = Verein für Deutsche Kulturbeziehungen im Ausland): SN 20/4; Zwjazkowa agentura za dźéło (BA = Bundesagentur für Arbeit): SN 42/2 (2×); Zwjazkowe sudnistwo (BGH = Bundesgerichtshof): SN 58/2; Zwjazkowe zjednoćenstwo ćišć a medije (BVDM = Bundesverband Druck und Medien): SN 124/2; Zwjazkowe zjednoćenstwo srjedźnostawskeho hospodarstwa w Hornjej Łužicy (BVMW = Bundesverband mittelständische Wirtschaft): SN 20/1 // Zwjazkowe zjednoćenstwo srjedźnostawskeho hospodarstwa (BVMW): SN 25/3 (3×) // Zwjazkowe zjednoćenstwo srjedźnostawskeho hospodarstwa Hornja Łužica (BVMW): SN 100/1 // Hornjolužiske Zwjazkowe zjednoćenstwo srjedźnostawskeho hospodarstwa (BVMW): SN 235/1; zwjazkowy wukonowy centrum (BLZ = Bundesleistungszentrum): SN 138/2; zwjazkowy zarjad za tworowy wobchad (BAG = Bundesamt für Güterverkehr): SN 80/2; železniski zwjazkowy zarjad (EBA = Eisenbahn-Bundesamt): SN 34/2.

\section{Toponimy (115)}

a) Ojkonimy (93): Běła (Biehla): SN 123/3; Bělšecy (Ebendörfel): SN-P 65/3; Bjedrichecy (Friedersdorf): SN-P 210/3; Bodricy (Boderitz): SN-P 25/3; Bónjecy (Binnewitz): SN-P 65/3; Brěznja (Wiesa): SN 143/4; Brězynka (Briesing): SN-P 146/3; Brěžki (Brieschko): SN-P 228/3; Brjazki (Brieske): SN 246/3; Bukowc (Bocka): SN 40/3; Bušeńka (Neuschmerlitz) SN-P 166/3; Carny Gózd (Schwarzheide): SN 64/2 (2×) // Čorny Gózd (Schwarzheide): SN 225/2 (nazwa dłuż. miasta w wersji dolno-i górnołużyckiej); Celovec (Klagenfurt): SN 62/8 (3×); Čorna hora (Schwarzenberg): SN-P 25/3; Debricy (Döbra): SN-P 166/3; Delany (Döhlen): SN-P 65/3; Dobrošecy (Doberschütz): SN-P 146/3; Drěžnica (Drieschnitz): SN 208/1; Gatojce (Teichland): SN 45/3; Gólišyn (Golßen): SN 144/1; Gózdź (Haidemühl): SN 29/3; Groźišćo (Grötsch): SN 135/8; Habrachćicy (Eberswalde): SN 145/1; Hamoršć (Hammerstadt): SN-P 20/3; Hermanecy (Hermsdorf): SN-P 210/3; Htušina (Glossen): SN-P 5/2; Hlinka (Kunnersdorf): SN 178/2; Hlinowc (Thonberg): SN-P 25/3; Hóznica (Petershain): SN 61/4 (3×); Hóznja (Hosena): SN 75/2 (2×); Hruboćicy (Grubditz): SN-P 65/3; Hus (Maust): SN 45/3; Chorecy (Georgewitz): SN 142/2 (por. głuż. Wiki: Korecy); Jama (Grube): SN-P 5/2; Jaseńca (Jeßnitz): SN-P 65/3; Jawornik (Jauernick): SN-P 5/2; Jeleńcy (Göllnitz): SN 68/2; Jemjelnica (Jamlitz): SN 177/2; Jědlow (Gödlau): SN 96/1; Jitro (Milstrich): SN-P 166/3; Kobjelin (Köbeln): SN 18/4 (2×); Konopotna (Cantdorf): SN 106/7; Kopańce (Neuhausen): SN 242/2 (4×); Košnojce (Koschendorf): SN 210/3 (2×); Łaz (Lohsa): SN-P 210/3; Łućo (Merzdorf): SN-P 210/3; [pólska wjes] Lugi (Friedersdorf): SN-KW 243/1; Łuwoćicy (Lautitz): SN-P 5/2; Łysa (Lausche): SN 106/8 (2×); Lejno (Geierswalde): SN 131/3; Lubjenc (Mehlteuer): SN-P 65/3; Maliń (Greifenhain): SN 210/2; Měrjow (Melaune): SN 11/3 (2×); Mrocna (Pretschen): SN 194/2; Mučnica (Mauschwitz): SN-P 5/2; Němcy (Dörgenhausen): SN-P 228/3; Nowa Niwa (Neu Zauche): SN 144/1; Nowa Wjes (Neudorf Klösterlich): SN-P 228/3; Nowe Wiki (Neupetershain): SN 213/2; Nowy Lubolń (Neuliebel): SN 17/1 (2×); Ochranow (Herrnhut): SN 32/2; Pawłecy (Wendisch-Paulsdorf): SN-P 5/2 (por. głuż. Wiki: Serbske Pawlecy); Plusnikecy (Pließkowitz): SN-P 146/3; Porchow (Burkau): SN-P 25/3; Prašyjce (Schönheide): SN 29/3; Protecy (Prietitz): SN-P 25/3; Radomierzyce (Radmeritz): SN-KW 223/4; Radyńc 
(Klein Radden): SN 232/3; Ramnow (Rammenau): SN-P 25/3; Rań (Großräschen): SN 66/2 (2×); Rančik (Rehnsdorf): SN 24/4 (2×); Rušica (Rauschwitz): SN-P 25/3; Sobołk (Zoblitz): SN-P 5/2; Splósk (Pielitz): SN-P 65/3; Stara Darbnja (Altdöbern): SN 132/2; Stary Lubolń (Altliebel): SN-P 20/3; Stróža (Wartha): SN-P 210/3; Śćé́ca (Steinitz): SN 210/3; Trušecy (Trauschwitz): SN-P 5/2; Tři Žony (Dreiweibern): SN-P 210/3 (dzielnica wsi Łaz); Walowy (Wohla): SN-P 5/2 (por. Völkel2005: Walow); Wjerto (Werda): SN-P 20/3; Wótrań (Ortrand): SN 197/4; Wujězd (Breitendorf): SN 151/3; Wulke Ždźary (Groß Särchen): SN-P 228/3; Wysoka (Weißig): SN-P 210/3; Załhozdź (Sallgast): SN 68/2; Złyčin (Litschen): SN-P 210/3; Železna Kapla (Eisenkappel): SN-KW 205/3; Željezno (Eisenstadt): SN 73/1(4×); Želnje (Sellendorf): SN 117/2; Žrobolce (Trebatsch): SN 116/1.

b) Oronimy (14): Byčin (Wohlaer Berg): SN-P 5/2; Čertowy kamjeń (Teufelsstein): SN 217/4 ; Dolina Wuježčanskeje wody / Wuježčanki (Wuischker Wasser): SN 169/4; Kokulowy kamjeń (Kuckucksstein): SN 217/4; Křrič (Gottlobsberg): SN 179/4; Lazkowski lěs (Lasker Auenwald): SN-P 166/3; Limas (Königshainer Berge): SN-P 65/3; Lubjenc (Mehlteuerberg): SN-P 65/3; Lubolńska wudolina (Neuliebelner Senke): SN-P 20/3; Mužakowski zahórk (Faltenbogen): SN 29/3 (por. Völkel2005: zahork); Sedto (Landeskrone) [pola Zhorjelca]: SN 154/4; Smjertny kamjeń (Totenstein): SN 217/4 ; Wódrowy tuh (Oderbruch): SN 16/2 (por. Tgeo: Wódriny tuh); Wysoki kamjeń (Hochstein): SN 217/4.

c) Hydronimy (8): Slěborny jězor (Silbersee): SN-P 210/3; Sprjewica (Kleine Spree): SN-P 210/3; Smólny hat (Pechteich): SN-P 20/3; Srjedźny hat (Mittelteich): SN-P 228/3; Stuchta hrjebja (Modergraben): SN-P 20/3; Tradowske haty (Tradoer Teiche): SN-P 166/3; Třižonjanski jězor (Dreiweiberner See): SN-P 210/3; Turjołučny hat (Tauerwiesenteich): SN 189/4.

\section{Słownictwo ogólne (49)}

a) Kulinaria (8): bělk (Eiweiß): SN-P 83/4 - 'białko'; ćěsto (Teig): SN-P 83/4 - 'ciasto'; jejkowa solotej (Eiersalat): SN-P 83/4 - 'sałata jajeczna'; jejkowy čwork (Eigelb): SN-P 83/4 - 'żółtko'; minimalna dźeržomosć (Mindesthaltbarkeit): SN-P 83/4 - 'przydatność do spożycia'; solotwjowe schadźenki (Salatsprossen): SN 108/2 - 'kiełki sałatkowe'; sykane mjaso (Hackepeter): SN-P 83/4 - 'mięso mielone'; zakładne žiwidła (Grundnahrungsmittel): SN-P 83/4 - 'podstawowe pożywienie'.

b) Leksyka fachowa (8): hladanske kruhi (Hegeringe): SN-P 248/5 - łow. 'koła ochrony przyrody'; hladanske zhromadźenstwa (Hegegemeinschaften): SN-P 248/5 - łow. 'związki ochrony przyrody'; łakańca (Hochsitz): SN 97/1 - łow. 'ambona'; metjer (Metteur): SN 211/4 - druk. 'metrampaż'; měchawa (Blasebalg): SN-P 248/6 - 'miech'; powětroškit (Luftschutz): SN 44/4 - wojsk. 'ochrona przeciwlotnicza'; šćerkawki (Rassel): SN 85/1 - muz. 'gruchawka'; wyšk (Obrist): SN-P 228/3 - wojsk. 'pułkownik'.

c) Słownictwo dawne (12): blokowe zahony (Blockfluren): SN-P 45/2 - 'blokowy układ pól (typ przestrzenny wsi)'; łanarjo (Hüfner): SN 9/4 - 'właściciele ziemscy'; łany / leny 
(Hufen): SN 194/4 (2×) - 'łany'; mjecki (Metzen): SN 130/4 - 'dawna jednostka objętości'; smoleńca (Pechhütte): SN 246/4 - 'smolarnia'; smolerstwo (Pechschwelerei): SN 246/4 - 'smolarstwo'; stawowa republika (Ständerepublik): SN-KW 35/2 - 'republika stanowa'; stražnik honow (Flurhüter): SN 124/4 - 'polowy, stróż polny'; towaršojo (Gesellen): SN 49/4 - 'czeladnicy'; wuhlenca (Kohlemeiler): SN 246/4 - 'mielerz'; wužiwar kubła (Gutsnutznießer): SN 102/6 - 'użytkownik majątku ziemskiego'; zežiwjenske pjenjezy (Ziehgeld): SN 96/4 - 'zasiłek'.

d) Inne (21): atomowa milinarnja (AKW = Atomkraftwerk): SN 108/2 - 'elektrownia atomowa'; centralna institucija (Kerneinrichtung): SN 155/5 - 'instytucja centralna'; čopiki (Stollen): SN 182/3 - 'kolce, korki (na butach)'; čućiwosć (Stimmungshaftigkeit): SN -KW 15/3 - 'wrażliwość'; ćéłowa žona (Leichenwäscherin): SN 67/4 - 'kobieta przygotowująca ciało zmarłego do pochówku, tranatopraktorka'; koncepcija príichoda (Zukunftskonzept): SN 180/3 - 'prognozowanie, koncepcja'; lěsyca (Gitter): SN-P 238/4 -'krata'; piwowe podkładki (Bierdeckel): SN 5/1 - 'podstawki, tekturowe podkładki do piwa'; porok (Abmahnung): SN 44/3 - 'upomnienie'; prećeženosć / wopačne poćeženje (Fehlbelastung): SN 213/5 - 'przeciążenie'; rodźiny (Sippen): SN 201/2 - 'plemiona, klany'; rozćahować so (dehnen): SN 182/3 - 'rozciągać się'; samolutnik (Einzelgänger): SN 153/3 - 'samotnik, odludek'; skalny park (Skalenpark): SN 111/4 - 'park skalny'; stód (Malz): SN-P 210/2 - 'słód'; wlečny lift (Schlepplift): SN-P 25/3 - 'wyciąg orczykowy'; wotpisanja (Abschreibungen): SN 243/2 - 'odpisy'; woženje njebohich (Leichenfuhren): SN 92/4 - 'odprowadzenie zwłok'; wyšnostny (hoheitliches): SN 33/3 - 'zwierzchni'; zajaty (befangen): SN 178/7 - 'stronniczy'; zezhibnyć (einknicken): SN-P 79/6 - 'zgiąć'.

\section{Analiza semantyczna i formalna objaśnianej leksyki}

Zgromadzony materiał jest niezwykle różnorodny pod względem semantycznym. Największą grupę stanowi terminologia naukowa, w której przeważa nomenklatura botaniczna i zoologiczna. Wynika to $\mathrm{z}$ obecności w gazecie stałej rubryki, w której poruszane są tematy związane z przyrodą i ochroną środowiska - Łužiska přiroda a wobswět. Z porównania materiału ze słownictwem zawartym w najnowszych górnołużyckich słownikach ogólnych (NHS, Noleks, Völkel2005) i terminologicznych (np. Tbio, Tgeo) wynika, że w przypadku terminologii chodzi najczęściej o objaśnianie leksyki mało znanej, rzadziej nowej (dotyczy to 37 ze 163 nazw, czyli niespełna 23\%). Autorzy mają problem z podaniem nazw gatunków rzadkich, których brak w języku górnołużyckim. Wyraźnie widać to w nazwach botanicznych. Autor używa wówczas zwykle ogólnej nazwy gatunku jako hiperonimu, zaś konkretyzuje ją nazwa niemiecka, np. stróžawka (Flockenblume) - 'chaber' i stróžawka (Wiesen-Flockenblume) - 'chaber łąkowy'. Niekiedy zaś dodatkowo poprzedza tę nazwę określeniem „rzadki gatunek”, por. Žadna družina dźećela (Streifenklee) ['koniczyna kreskowana'] abo stróžawki (Rispen-Flockenblume) ['chaber nadreński']. Tego typu jednostek nie włączono do statystyki.

Nieliczne nowe nazwy i terminy to kalki nazw i terminów niemieckich, por. lobjowski bobr (Elbebiber), wotmaty nosorohač (Wollnashorn), dwublyšćinkowy zornowc (Zweiglimmergranit), šćépjelowy płun (Schiefergas), zakładny wukon (Grundlast). Jak widać z po- 
wyższych przykładów, niemieckim wyrazom złożonym odpowiada w języku górnołużyckim nazwa o strukturze: przymiotnik + rzeczownik. Rzadziej jest to połączenie rzeczownik + grupa przyimkowa, por. wowca z wjacorymi rohami (Mehrhornschaf). Wyjątek stanowi tu termin škleńčowina (Flüssigglas) - wyraz utworzony od podstawy škleńca (niem. Glas) za pomocą sufiksu -(ow)ina (produktywny w tworzeniu nazw substancji i surowców).

Druga (częściowo również trzecia) wyróżniona kategoria odnosząca się do życia społecznego odzwierciedla zmiany społeczne (por. patchworkowe swójby 'rodziny patchworkowe') oraz ekonomiczne (por. akcijna towaršnosć 'spółka akcyjna'), jakie dokonały się w ostatnich latach. Jest to słownictwo niemal w połowie nowe.

Nazwy różnego rodzaju instytucji, urzędów i organizacji (wyróżnione tutaj jako osobna kategoria, niezależnie od ich znaczenia i przynależności dziedzinowej) to najczęściej nazwy własne, rzadziej nazwy pospolite (np. ratarske prodrustwo 'spółdzielnia produkcyjna’). W zdecydowanej większości są to jednostki nowe. Tylko nieliczne (24 ze 106, czyli niespełna 23\%) rejestruje Noleks, sporadycznie NHS. Nowe nazwy są mniej lub bardziej udanymi tłumaczeniami nazw niemieckich. Materiał pokazuje, że jest to leksyka dość labilna. Wyraźnie widać, że autorzy największy problem mają z przekładem komponentu przymiotnikowego: niekiedy odpowiada mu przydawka przymiotna, innym razem rzeczowna, por. Sakski krajny ratarski zwjazk (SLB = Sächsischer Landesbauernverband) // Sakski krajny zwjazk ratarjow // Krajny zwjazk sakskich ratarjow. Można też odnieść wrażenie, że autorzy tekstów tłumaczą nazwę ad hoc, mimo że rejestrują ją słowniki, np. Němski zwjazk žurnalistow (DJV = Deutscher Journalistenverband) // Němski žurnalistiski zwjazk - por. Noleks: Zwjazk žurnalistow Němskeje.

Badaniem objęto również toponimy, które nie były ujmowane w dotychczasowych opracowaniach objaśnianej nawiasowo leksyki (por. Markec). Jako mało znaną bądź nieznaną, toponimię rejestrują również górnołużyckie słowniki. W zgromadzonym materiale są to najczęściej słabo znane nazwy miejscowości górno- i dolnołużyckich (słowniki odnotowują zaledwie $19 \mathrm{z}$ nich, czyli ponad 16\%). Problem stanowi jednak nie tylko kwestia znajomości tych nazw, ale jak pokazuje materiał, również ich odmiana, por. Kopańce (Neuhausen): SN 242/2, blisko Kopańcy (Neuhausen): SN 243/2, w Kopańce (Neuhausen): SN 244/2, w Kopańcach (Neuhausen): SN 125/2.

Objaśniane bywa również słownictwo ogólne. W zebranym materiale znalazły się wyrazy o różnym charakterze. Jest to słownictwo fachowe oraz wyrazy z dziedziny kulinariów. Nie brak też leksyki dawnej.

Należy zaznaczyć, że w prasie pojawiają się również inne objaśnienia nawiasowe, które nie zostały objęte analizą. Są to:

- nazwy i tytuły będące subiektywnymi tłumaczeniami autorów, np. Štom lèta mjenuje so ludowje „rjana Hilža“ (schöne Else): SN 13/4, w hosćencu „Burska stwička “ (Bauernstübl): SN-P 228/3 itp.,

- parafrazy terminów niemieckich, np. wulka garaža za lětadła (Hangar): SN-P 5/2, pjeć najgrošow pristajenskeho zrěčenja (Mietgeld): SN 59/4,

- wyrazy ogólne, które konkretyzuje niemieckie objaśnienie, np. porjad (Rangordnung): SN 28/4, woprawnjenka (Bundesjagdschein): SN-P 248/5,

- wyrazy obcego pochodzenia z objaśnieniem górnołużyckim, np. almanachi (swjedźenske spisy): SN 8/2, aklamacija (zběhnjenje ruki): SN 4/6, coockieje (poprjančki): SN-M 126/3, 
- górnołużyckie nazwy objaśniane przez inne górnołużyckie wyrazy (synonimy), np. nócne mjetele (nócniki): SN 101/4, rybornicy (mórske tastojcy): SN 189/4,

- połączenia wyrazowe będące przekładami z innych języków (głównie angielskiego), np. rubanje drjewa (woodchop): SN-M 93/3, runa smuha (longline): SN 19/3,

- przekłady frazeologizmów, np. To rěka naposledk by jenož měnjenje abo žadanje toho plaćiło, kotryž sedźi za dlěšej ručicu (am längeren Hebel), kotryž wobsedźi móc abo pjenjezy: SN 184/3 - por. niem. am längeren Hebel sitzen 'ma silniejszą pozycję od przeciwnika'.

\section{Podsumowanie}

Górnołużycka prasa, zwłaszcza zaś „Serbskie Nowiny”, ma duży wpływ na tworzenie nowej i upowszechnianie mniej znanej leksyki. W tym drugim wypadku decyduje dokonana przez autora tekstu subiektywna ocena sytuacji językowej i znajomości danego wyrazu przez odbiorców. Zgromadzony tu materiał po pierwsze prezentuje niezwykle bogate pod względem semantycznym słownictwo, z którym na co dzień muszą mierzyć się dziennikarze. Po drugie, pokazuje, że autorzy niekiedy dość spontanicznie zaproponować muszą nowy wyraz lub posłużyć się istniejącym wyrazem ogólnym, który konkretyzuje niemieckie objaśnienie nawiasowe. Choć w swych poczynaniach nie są oni wolni od błędów, to jednak pozytywnie ocenić należy rolę prasy górnołużyckiej w kształtowaniu słownictwa literackiej górnołużycczyzny oraz świadomości językowej jej użytkowników.

\section{Bibliografia}

Bura R., 2012, „, Lužiski serbski słownik” K.B. Pfula jako słownik „odrodzeniowy”, „Slavia Occidentalis" 69, s. 81-89.

Kral J., 1927, Serbsko-němski stownik hornjotužiskeje rěče, Budyšin.

Lewaszkiewicz T., 1980, Über eine bestimmte Methode der Erklärung und Verbreitung von Lexik in der sorbischen Presse, „Lingua Posnaniensis” XXIII, s. 129-135.

Lewaszkiewicz T., 1994, Rola prasy górnołużyckiej z lat 1842-1853 w ksztattowaniu słownictwa języka literackiego (Rekonesans badawczy), w: Uwarunkowania i przyczyny zmian językowych, „Język na Pograniczach” 11, Warszawa, s. 71-85.

Lewaszkiewicz T., 1995, Rola prasy łużyckiej w ksztaltowaniu świadomości narodowej, upowszechnianiu kultury i rozwoju języków tużyckich, „Zeszyty Łużyckie” t. 13, nr 2 [14]: Własne drogi rozwoju tużyckich języków literackich, s. 27-35.

Markec J., 2000, Němske rozjasnjenja noweje abo mało znateje leksiki w serbskich nowinach, „Sorapis" 1 , s. 54-76.

NHS = Jenč H., Michałk F., Šěrakowa I., 1989,1991, Deutsch-obersorbisches Wörterbuch / Němsko -hornjoserbski słownik, przy współpracy J. Měrćinka, t. 1., t. 2., Bautzen / Budyšin.

Noleks = Jenč H., Pohončowa A., Šołćina J., 2006, Deutsch-obersorbisches Wörterbuch neuer Lexik / Němsko-hornjoserbski słownik noweje leksiki, Bautzen.

Tbio = Šołta J., 1995, Terminologija za předmjet biologija. Němsko-hornjoserbsce. Hornjoserbsko-němsce, Budyšin.

Tgeo = Mehrowa H., Pawlikowa B., 1996, Terminologija za předmjet geografija. Němsko-hornjo-serbsce. Hornjoserbsko-němsce, 2., rož̌ěrjeny nakład, Budyšin. 
Tsta = Zahrodnik L., 1995, Terminologija za předmjet stawizny. Němsko-hornjoserbsce. Hornjo-serbsko-němsce, Budyšin.

Völkel2005 = Völkel P., 2005, Prawopisny słownik hornjoserbskeje rěče. Hornjoserbsko-němski słownik / Obersorbisch-deutsches Wörterbuch, wobdźěłał Timo Meškank, 5., wobdźěłany a sylnje rozšěrjeny nakład, Bautzen.

Wiki = Wikipedija: https://hsb.wikipedia.org/wiki/H\%C5\%82owna_strona

\section{RENATA BURA}

\section{German Parenthetic Glosses in the Upper Sorbian Press}

\section{Summary}

The extraction of Upper Sorbian vocabulary with German glosses in parentheses allowed researchers to collect, in a short time, rich lexical material for study and to conduct statistical analyses, which, to some extent, helped to evaluate the role of the Upper Lusatian press in the development of the lexis of this language. The vocabulary extracted from the daily newspaper Serbske Nowiny (the issues of 2011) proved to be very interesting semantically. This collection of words illustrates the development of the Upper Sorbian lexis and reflects the social and economic changes which have taken place in recent years. The words explained in parentheses were poorly known or new.

Keywords: Upper Sorbian language, Upper Sorbian lexis, German (parenthetic) glosses, Upper Sorbian press 
